\title{
Model Rancangan Rumah Susun Di Kampung Wisata Jetisharjo Yogyakarta Dengan Pendekatan Green Landscape Dan Green Facade
}

\author{
${ }^{1)}$ Suparwoko; ${ }^{2}$ Piana Dewi \\ ${ }^{1)}$ Dosen Program Arsitektur Universitas Islam Indonesia \\ ${ }^{2)}$ Mahasiswa Program Arsitektur Universitas Islam Indonesia \\ Email : wokosuparwoko@gmail.com
}

\begin{abstract}
Abstrak
Tujuan penulisan adalah merencanakan dan merancang rumah susun di permukiman kampung wisata Jetisharjo dengan penekanan Green Landscape dan Green Facade. Permasalahan lingkungan di sekitar kali Code merupakan pemukiman yang sangat padat dan sebagian di antaranya kumuh dan kurang ruang terbuka hijau. Di lingkungan perkotaan Yogyakarta, khusunya di kawasan pinggiran sungai Code, dapat dinilai kurang berkembang pada aspek tata lingkungan landscape maupun facade bangunan. Konsep tersebut sangat relevan dengan pendekatan green architecture sebagai metoda yang digunakan dalam mewujudkan arsitektur ekologis atau ramah lingkungan untuk mencapai keseimbangan pada sistem interaksi manusia dengan lingkungan. Metoda untuk memperoleh data dilakukan dengan cara pengambilan data primer dan sekunder. Data primer berupa kondisi sosial fisik lingkungan lokasi perencanaan dilakukan dengan pencatatan, wawancara, dan pengambilan gambar (foto dan internet). Sedangkan data sekunder berupa data statistik dan literatur diperoleh melalui pencarian pada media internet dan perpustakaan. Metoda analisis perancangan lansekap dilakukan dengan penetapan green open space strategi yang mengedepankan aspek civic space dan kind of vegetation. Adapun analisis green facade dilakukan dengan strategi perancangan green roof dan green wall. Diharapkan pendekatan tersebut akan memberikan citra dan estetika lingkungan rumah susun yang ramah terhadap lingkungan pinggiran suangai. Studi kasus perencanaan berada di kampung wisata Jetisharjo, Yogyakarta yang sebagian berada di bantaran kali Code Yogyakarta. Analisis perundangan tata bangunan dan lingkungan serta kebijakan green landscape yang akan menghasilkan zona-zona yang ramah lingkungan dimana ruang terbuka hijau direncanakan lebih besar dibanding luas maksimum diijinkan oleh peraturan daerah setempat, sehinga perlu adanya insentif menambah ruang hijau perkotaan. Hasil yang diharapkan adalah suatu masterplan untuk sebagai dasar penataan landscape dan perancangan bangunan rumah susun dengan penekanan Green Landscape dan Green Facade.
\end{abstract}

Kata Kunci : rumah susun, Jetisharjo, green landscape, green facade

\section{PENDAHULUAN}

\subsection{Kunjungan Wisatawan Yogyakarta}

Jumlah penduduk DIY selalu bertambah setiap tahun, namun laju pertumbuhannya cenderung berfluktuasi. Laju pertumbuhan penduduk selama periode 1971-1980 tercatat sebesar 1,10 persen per tahun. Meskipun demikian, dalam sepuluh tahun terakhir (2000-2010) laju pertumbuhan penduduk kembali meningkat menjadi 1,04 persen per tahun. Fenomena ini berkaitan dengan semakin menurunnya angka kematian dan meningkatnya angka harapan hidup serta semakin bertambahnya migrasi masuk dengan tujuan bersekolah atau bekerja (BPS Kota Yogyakarta, 2012). Namun demikian, di Kota Yogyakarta, permukiman kumuh tercatat mencapai 278,7 hektar atau setara dengan 8,17 persen luas wilayah. Dari jumlah wilayah kumuh tersebut, 90 persen di antaranya berlokasi di bantaran sungai . 


\subsection{Kunjungan Wisatawan Yogyakarta}

Dalam bidang pariwisata, Yogyakarta memiliki banyak tempat wisata, baik wisata alam, budaya, religi, belanja, kuliner dan sebagainya. Dengan potensi wisata yang cukup lengkap, Yogyakarta juga banyak memberikan daya tarik tersendiri bagi wisatawan antara lain, alam sekitar jogja yang indah, budaya yang masih asli dan kental dimana budaya modern dapat berbaur dengan budaya tradisonal serta keramahan warganya yang membuat Yogyakarta semakin diminati wisatawan domestik dan mancanegara.

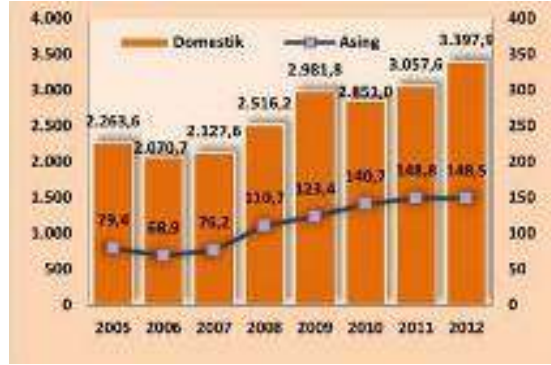

Gambar 1. Jumlah Wisatawan Domestik dan Asing ke DIY, 20052012 (BPS Kota Yogyakarta, 2012)

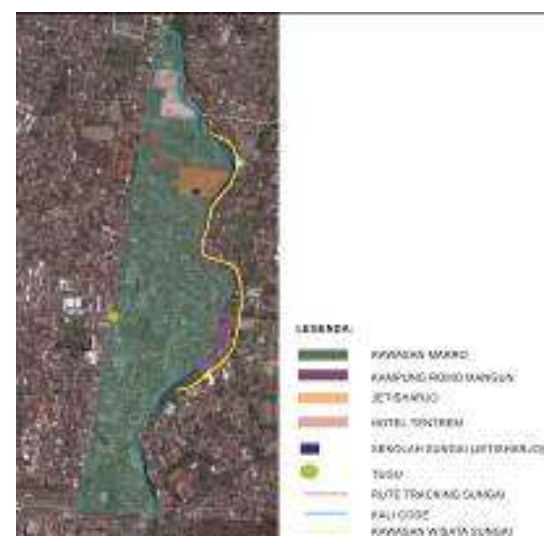

Gambar 2. Rute Wisata Kali Code (Pratopo, 2014)

Dari berbagai macam tempat wisata di Yogyakarta, kampung wisata saat ini mulai dijadikan pilihan wisatawan untuk berwisata sekaligus mempelajari adat dan budaya di ebuah kampung wisata tersebut. Salah satunya adalah kampung wisata Jetisharjo yang memiliki kegiatan wisata berupa tracking sungai dan sekolah sungai, rute tracking sungai meliputi Kewek - Kampung Romo Mangun - Kampung Jetsharjo, Sedangkan untuk sekolah sungai diselenggarakan pada ruang terbuka di tepian sungai (Pratopo, 2014). Kunjungan wisatawan domestik maupun mancanegara ke kampung wisata cukup banyak mengingat saat minimnya promosi maupun pemberitahuan tentang kampung wisata ini, pada tahun 2014 terdapat sekitar 600 wisatawan yang terdiri dari instansi, peneliti, mahasiswa, pemda, pkk luar daerah, termasuk wisatawan asing (Pratopo, 2014). Namun secara umum kawasan permukiman Code dinilai kumuh dan kurang teratur (Pangkerego, 2014), karena lansekap dan fasad bangunan yang kurang memperhatikan potensi pembangunan terpadu antara potensi masyarakat berpenghasilan rendah dan masyarakat kelas menengah yang mungkin bisa diintegrasikan dalam satu wujud bangunan vertikal multi penggunaan secara bersama. 


\section{Tujuan dan Sasaran}

1. Tujuan

Tujuan kajian ini adalah untuk merencanakan dan merancang rumah susun di Kampung Jetisharjo Yogyakarta dengan pendekatan Green Landscape berbasis kebutuhan Civic Space dan Green Facade sebagai media tanaman pangan.

2. Sasaran

a. Analisis dan perancangan zonasi kampung wisata yang mencakup letak blok, sirkulasi dan fasilitas masyarakat sekitar

b. Analisis aktivitas dan kebutuhan ruang rumah susun

c. Analisis dan perancangan landsekap dengan pendekatan Green Open Space Strategy yang mencakup pembahasan materi Civic Space dan Kind of Vegetation

d. Analisis dan perancangan Green Facade dengan pendekatan Green Roof dan Green Wall pada dinding rumah susun dengan sistem modular pada dinding, teras dan bukaan.

\section{KAJIAN RUMAH SUSUN DENGAN PENDEKATAN GREEN LANDSCAPE DAN $F A C A D E$}

\subsection{State of the Art}

State of the Art pada penulisan makalah ini dapat dilihat pada Tabel 1.

Tabel 1. Kajian Model Perencanaan dan Perancangan Sejenis

\begin{tabular}{|l|l|l|l|}
\hline \multicolumn{1}{|c|}{ Lokasi } & \multicolumn{1}{|c|}{ Tema/Judul } & \multicolumn{1}{c|}{ Permasalahan } & \multicolumn{1}{c|}{ Penulis } \\
\hline DKI Jakarta & $\begin{array}{l}\text { Perancangan Kembali } \\
\text { Kawasan Perumahan } \\
\text { Kampung Pulo di } \\
\text { Tepi Sungai Ciliwung }\end{array}$ & $\begin{array}{l}\text { Prinsip dan konsep perancangan kawasan } \\
\text { perumahan Kampung Pulo, berupa kawasan } \\
\text { perumahan vertikal (rumah susun) setinggi 10 lantai } \\
\text { dengan 8 lantai bersifat adaptif di kawasan rawan } \\
\text { banjir, serta dapat menyelesaikan persoalan praktis } \\
\text { di wilayah penelitian. }\end{array}$ & $\begin{array}{l}\text { Pangkerego, } \\
\text { Gabriel Efod } \\
\text { Virant, 2014 }\end{array}$ \\
\hline Surabaya & $\begin{array}{l}\text { Rumah Susun Kali } \\
\text { Jagir }\end{array}$ & $\begin{array}{l}\text { Rumah susun ini didesain dengan menggunakan } \\
\text { pendekatan perilaku dan memperhatikan } \\
\text { penghawaan dan pencahayaan alami, material lokal, } \\
\text { dan system konstruksi yang murah dan sederhana., } \\
\text { dengan pendekatan pendalaman infill desain. }\end{array}$ & $\begin{array}{l}\text { Agung } \\
\text { Suryajaya, } \\
\text { 2013 }\end{array}$ \\
\hline $\begin{array}{l}\text { Yogyakarta } \\
\text { dengan }\end{array}$ & $\begin{array}{l}\text { Kampung Vertikal } \\
\text { Bantaran Sungai } \\
\text { Code Pendekatan }\end{array}$ & $\begin{array}{l}\text { Konsep dasar perencanaan dan perancangan } \\
\text { Kampung Vertikal ini menitikberatkan pada } \\
\text { perancangan dengan mempertahankan suasana }\end{array}$ & $\begin{array}{l}\text { Cherya } \\
\text { Mayndra } \\
\text { Nurfeta, 2013 }\end{array}$ \\
\hline
\end{tabular}




\begin{tabular}{|c|c|c|c|}
\hline & Arsitektur Organik & $\begin{array}{l}\text { kampung sebelumnya dan diharapkan dapat } \\
\text { memperbaiki kualitas hidup manusia dan } \\
\text { lingkungan (sungai) }\end{array}$ & \\
\hline Yogyakarta & Rumah Susun & $\begin{array}{l}\text { mewujudkan suatu "Kampung Vertikal" supaya } \\
\text { proses resettlement masyarakat dengan pendekatan } \\
\text { Teori Hirarki Kebutuhan Manusia menurut } \\
\text { Abraham Maslow (1943), yang pada akhirnya akan } \\
\text { diwujudkan dalam penataan ruang luar dan ruang } \\
\text { dalam bangunan Rumah Susun }\end{array}$ & $\begin{array}{l}\text { Nestor } \\
\text { Raditya } \\
\text { Manohara } \\
2011\end{array}$ \\
\hline
\end{tabular}

Berdasarkan perbandingan judul kajian rumah susun, maka tema Model Rancangan Rumah Susun di Kawasan Wisata Jetisharjo Yogyakarta dengan pendekatan Green Landscape dan Green Facade memiliki kebaruan yang signifikan.

\subsection{Aktifitas Rumah Susun}

Aktivitas pada rumah susun terdiri dari empat 5 tipe penghuni yaitu lajang, pasangan, keluarga, wisatawan dan penyewa retail. Serta terdapt 4 kategori pelaku aktivitas yaitu, penghuni, wisatawan, pengelola, penyewa retail atau pedagang yang masing-masing memiliki pola aktivitas yang berbeda. Analisis aktifitas ditinjau dari indikator aktivitas yang memiliki variabel penghuni, wisatwan, dan pengelola dan penyewa tempat usaha. Masing-masing variabel memiliki tolok ukur yang akan disusun dengan sistem tabulasi sepert pada Tabel 2. Tolok ukur pada aktivitas rumah susun meliputi pola aktivitas dan kebutuhan ruangnya. 
Tabel 2. Analisis Aktivitas Penghuni Rumah Susun

\begin{tabular}{|c|c|c|c|}
\hline Indikator & Pengguna & Variabel (pola aktivitas) & Tolok Ukur (fasilitas) \\
\hline \multirow[t]{42}{*}{ AKTIVITAS } & PENGHUNI & - Jalan kaki & Pedestrian, sirkulasi \\
\hline & & - Kendaraan & - $\quad$ Parkir kendaraan \\
\hline & & $\begin{array}{l}\text { - Melakukan aktivitas keseharian } \\
\text { - Tidur } \\
\text { - Makan } \\
\text { - Masak } \\
\text { - Mandi } \\
\text { - Duduk }\end{array}$ & $\begin{array}{l}\text { - Kebutuhan Ruang: } \\
\text { - Ruang tidur } \\
\text { - Dapur } \\
\text { - Dapur } \\
\text { - Kamar mandi } \\
\text { - Ruang tamu/keluarga }\end{array}$ \\
\hline & & - Makan dan minum (membeli) & - Retail \\
\hline & & - Membeli perlengkapan & - $\quad$ Retail \\
\hline & & - Berkumpul & - Public space \\
\hline & & - $\quad$ Refre shing & - Open space \\
\hline & & - Ibadah & - Musholla \\
\hline & WISATAWAN & - Jalan kaki & Pedestrian, sirkulasi \\
\hline & & - Kendaraan & - $\quad$ Parkir kendaraan \\
\hline & & - Recepcionist & - Lobby \\
\hline & & - Mencari informasi & - Ruang informasi \\
\hline & & $\begin{array}{ll}\text { - } & \text { Makan dan minum } \\
\text { Membeli barang 1ain }\end{array}$ & - $\quad$ Retail \\
\hline & & - Refreshing & - Open space \\
\hline & & - $\mathrm{BAB}, \mathrm{BAK}$, Higienis & - Toilet \\
\hline & & - Ibadah & - Musholla \\
\hline & & - $\quad$ Istirahat & $\begin{array}{l}\text { - Tempat duduk } \\
\text { - Taman, open space }\end{array}$ \\
\hline & & $\begin{array}{rll}- & \text { Melakukan aktivitas pribadi } \\
- & \text { Tidur } \\
- & \text { Makan } \\
- & \text { Masak } \\
- & \text { Mandi } \\
- & \text { Duduk/Keluarga }\end{array}$ & $\begin{array}{ll}- & \text { Kamar } \\
- & \text { Ruang tidur } \\
- & \text { Dapur } \\
- & \text { Dapur } \\
- & \text { Kamar mandi } \\
- & \text { Ruang tamu/ keluarga }\end{array}$ \\
\hline & PENGELOLA & - Jalan kaki & - $\quad$ Pedestrian, sirkulasi \\
\hline & & - Kendaraan & - Parkir kendaraan \\
\hline & & - Menyimpan barang & - R. Loker pengelola \\
\hline & & - Bekerja & - R. Pengelola \\
\hline & & - Pelayanan Informasi & - R. Informasi \\
\hline & & - Pelayanan kemanan & - R. Security \\
\hline & & - $\quad$ Service Building & - R. MEE, Cleaning Servis, Genset \\
\hline & & - Makan dan Minum & Retail \\
\hline & & - $\mathrm{BAB}, \mathrm{BAK}$, Higienis & Toilet \\
\hline & & - Ibadah & - Musholla \\
\hline & & - Istirahat & - $\quad$ Tempat duduk \\
\hline & $\begin{array}{l}\text { PENYEWA } \\
\text { TEMPAT USAHA }\end{array}$ & - Jalan kaki & - $\quad$ Pedestrian, sirkulasi \\
\hline & & - Kendaraan & Parkir kendaraan \\
\hline & & - Mengatur meja dan kursi & - Ruang makan dan minum \\
\hline & & $\begin{array}{l}\text { Membuat dan menyiapkan makanan } \\
\text { dan minuman }\end{array}$ & - Dapur \\
\hline & & - Mengantar makanan dan minuman & Ruang makan \&minum \\
\hline & & - Mencuci peralatan & - Dapur \\
\hline & & - Pelayanan konsumen & $\begin{array}{ll}\text { - } & \text { Ruang makan \& minum } \\
\text { Kasir }\end{array}$ \\
\hline & & - Makan dan minum & - Ruang makan \\
\hline & & - $\quad$ BAK, BAB, Higienis & - Toilet \\
\hline & & - Ibadah & Musholla \\
\hline & & - Istirahat & - Tempat duduk \\
\hline & & - Jalan kaki & - Pedestrian, sirkulasi \\
\hline & & - Kendaraan & - Parkir kendaraan \\
\hline
\end{tabular}

\subsection{GREEN LANDSCAPE}

Green Landscape merupakan cara merancang yang efektif dan pemeliharaan taman yang indah dan lansekap umum untuk: 1) Meminimalkan kerusakan pada lingkungan alam, 2) Memaksimalkan fungsi ekologis landscape, 3) Hemat waktu dan uang dengan pemeliharaan dan persyaratan yang lebih rendah , 4) Menciptakan tempat sehat dan aman bagi orang untuk hidup, bekerja dan bermain (Environmental Planning and Climate Protection Department, 2010).

Bagian berikut eksplorasi manfaat utama dari Green Landscape pada Rumah Susun Jetisharjo mencakup: 1) lingkungan hidup yang lebih baik, 2) Biaya Tabungan, air dan energy, 3) Konservasi keanekaragaman hayati, 4) Melindungi dan memperkaya sumber tanah, 5) Perlindungan Iklim. 
Sedangkan Aspek Green Landscape (Environmental Planning and Climate Protection Department, 2010) meliputi:

- Soft Landscape: 1) Lansekap alami, 3) Green roof, 3) Vegetasi

- Hard landscape: 1) Furniture lansekap, 2) Penerangan, 3) Efisiensi air, 4) Penanda, 5) Perkerasan, 6) Menstabilkan saluran drainase

\subsection{GREEN OPEN SPACE STRATEGY}

Ruang terbuka harus diartikan semua terbuka sebagai ruang publik, bukan hanya tanah, tetapi juga daerah air seperti sungai, kanal, danau dan waduk yang menawarkan peluang untuk olahraga dan rekreasi dan dapat juga sebagai estetika yang dapat dinikmati oleh visual (CABE, 2006).

\subsection{GREEN FACADE}

Berdasarkan kajian tentang Green Facade, dari 3 variabel Green Facade System didapatkan tolok ukur keberhasilan Green Facade sebagai parameter dalam keberhasilan suatu desain (City of Melbourne, 2013). Green facade dengan sistem Modular Green Wall yang mencakup 1) Komponen tanaman ditempel (dinding), 2) Komponen tanaman digantung (dekat jendela dan dinding), 3) Komponen tanaman digantung dekat jendela dan dinding rumah susun. Pada tipe tanaman digantung (pada jendela dan dinding) cara sebagai berikut:

1) Menggunakan modul yang terbuat dari kawat

2) Menggunakan tanaman produktif dan tanaman hias yang bisa dimanfaatkan dan memberikan estetika.

3) Tanaman produktif ditempatkan pada sisi sebelah timur untuk mendapatkan panas matahari secara efektif, sedangkan tanaman hias diletakkan di sisi lainnya.

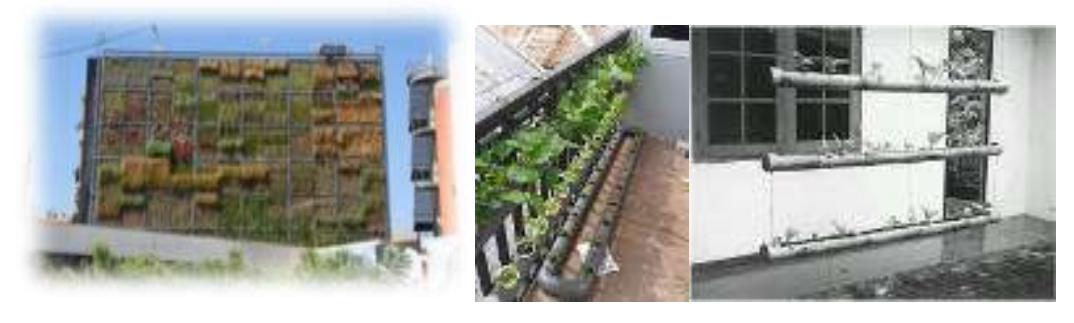

Gambar 3. Modular Green Wall 


\section{ANALISIS GREEN LANDSCAPE DAN GREEN FAÇADE pada Rumah Susun Jetisharjo}

Arsitektur hijau merupakan metoda yang digunakan dalam mewujudkan arsitektur ekologis atau ramah lingkungan untuk mencapai keseimbangan pada sistem interaksi manusia dengan lingkungan. Arsitektur hijau memiliki karakter minim konsumsi sumber daya alam serta minim terhadap dampak negatif terhadap lingkungan. Sehingga arsitektur hijau merupakan alat untuk merealisasikan pembangunan berkelanjutan. Aplikasi arsitektur hijau akan mampu menciptakan perwujudan arsitektur berkelanjutan (Karyono, 2010 dan Asikin et al., 2013)

\subsection{Penataan Kawasan}

Pengadaan rumah susun, berdasarkaan UU no 20 tahun 2011 tentang Rumaah Susun, adalah untuk memfasilitasi penyediaan rumah susun bagi masyarakat dan memfasilitasi penyediaaan prasarana, sarana, dan utilitas umum bagi rumah susun yang disediakan terutama untuk MBR.

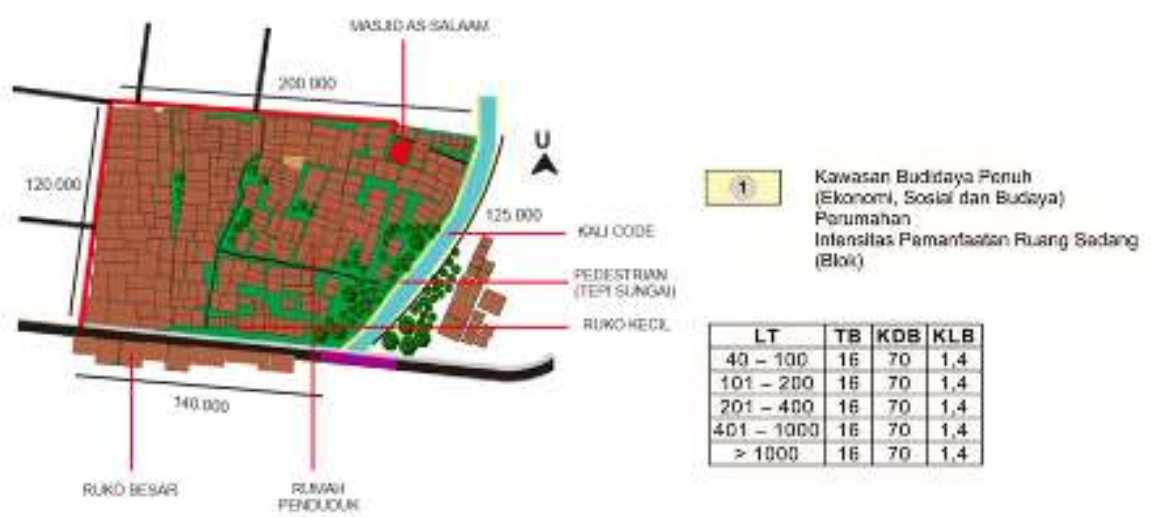

Gambar 4. Pemetaan Data Rumah di Kawasan Jetisharjo

Penataan Rumah di kawasan Jetisharjo mencakup: 1) Jumlah KK 252 kk, 2) Luas wilayah : $19.800 \mathrm{~m}^{2}$, 3) Panjang bantaran kali : $200 \mathrm{~m}$, 4) Jumlah Penerima KMS : 64, dengan Asset Kampung mencakup:Air Bersih Tirta Kencana, Koperasi 31, Masjid As-Salaam, Klinik Gratis, Relawan Banjir, Pengelola Wisata Code, Kelompok Tani, PAUD, TPA, LANSIA, Balai RW, Septiktank komunal, Taman RW, Pedestrian pinggir kali dengan lebar $2 \mathrm{~m}$ sepanjang $50 \mathrm{~m}$.

\subsection{Zonasi Kampung Wisata Jetisharjo}

Penetapan zonasi dan lokasi pembangunan rumah susun (UU No. 20 tahun 2011 dan Direktorat Jenderal Penataan Ruang, Departemen Pekerjaan Umum) harus dilakukan sesuai dengan ketentuan rencana tata ruang wilayah kabupaten/kota. Menurut Peraturan Walikota Yogyakarta 
tentang pembagian kawasan, zonasi dan intensitas pembangunan bahwa kawasan Kampung Jetisharjo (pada lokasi sekiar jembatan Sarjito) diperuntukkan bagi perumahan, jasa dan perkantoran dengan maksimum KDB 70\%-80\%, tinggi bangunan 20 s/d 24 meter.

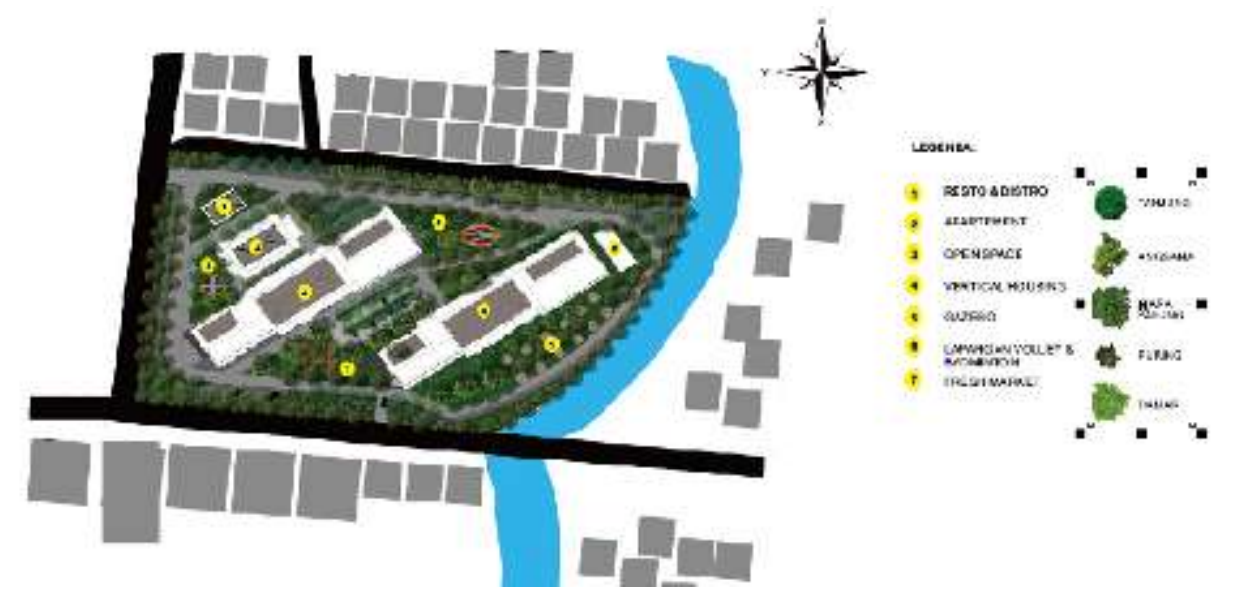

Gambar 5. Masterplan Penataan Kampung Jetisharjo

Penentuan blok didasarkan atas tujuan pola ruang kota yang efektif untuk kemudahan akses pada masin-masing masa bangunan (Shirvani, 1985). Sejumlah masa bangunan pada rumah susun Jetisharjo yang terdiri dari bangunan apartemen, vertikal housing, resto, dan distro yang kesemuanya secara efektif mudah dijangkau melalui jalan utama blok rumah susun tersebut.

Selanjutnya rancangan rumah susun di kawasan wisata Jetisharjo ini ditetapkan memiliki KDB 50\%-60\% untuk menambah RTH yang akan memberikan kontribusi pada aspek Micro Climate. Dengan pendekatan insentif RTH tsb. maka tinggi bangunan $24 \mathrm{~m}$ (7 lantai) menjadi $28 \mathrm{~m}$ (8 lantai). Pemerintah Kota Yogyakarta harus mengembangkan agenda yang pentinguntuk meningkatkan ruang terbuka hijau pada lahan privat dengan meningkatkan KLB jika mereka membangun RTH dengan cara menurunkan KDB 10\% - 30\% dari maksimum yang telah ditetapkan pada lokasi ybs. (Suparwoko, 2013).

Pada rancangan masterplan terdiri dari 7 zona sebagai fasilitas pada kampung wisata, antara lain komersil, hunian, rekreasi, masing-masing zona dipecah lagi dan kemudian menghasilkan 7 area yang menyediakan berbagai kebutuhan untuk kalangan menengah keatas dan menengah kebawah antara lain, resto \& distro, apartemen, open space yang terdapat pada setiap zona, rumah susun, gazebo, lapangan volley - badminton dan fresh market yang menyediakan sayur dan buah segar. 


\subsection{Rancangan Hunian Rumah Susun}

Terdapat 3 tipe kamar pada desain rumah susun Jetisharjo yaitu tipe studio, tipe couple dan tipe family yang disesuaikan dengan penghuni dan wisatawan. Masing-masing kamar terdapat ruang tidur, ruang keluarga, dapur dan kamar mandi, khisis untuk tipe studio hanya terdapat kamar mandi dan ruang fleksibel yang bisa di layout sesuai dengan kebutuhan penghuni. Rancangan tersebut didasarkan pada Undang-undang No. 15 pasal 3 tahun 1985 tentang pembangunan rumah susun, khususnya pada dasar penguna rumah susun yang mencakup jenis: singgle/lajang, pasangan, dan keluarga. Sehingga desain untuk hunian adalah Tipe $18 \mathrm{~m}^{2}$, Tipe $27 \mathrm{~m}^{2}$ dan tipe $36 \mathrm{~m}^{2}$ (lihat Gambar 7).
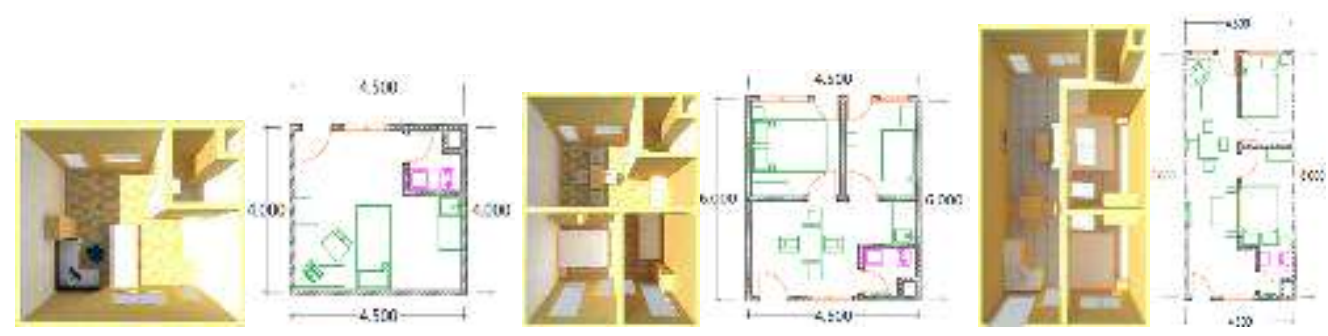

Gambar 6. Tipe Hunian Rumah Susun

\subsection{Denah dan Tapak Bangunan}

Berdasarkan UU No. 20 tahun 2011 "Fasilitas lingkungan rumah susun" merupakan sebidang tanah dengan batas-batas yang jelas yang di atasnya dibangun rumah susun, termasuk prasarana, sarana, dan utilitas umum yang secara keseluruhan merupakan kesatuan tempat permukiman. "Prasarana rumah susun" merupakan kelengkapan dasar fisik lingkungan hunian rumah susun yang memenuhi standar tertentu untuk kebutuhan tempat tinggal yang layak, sehat, aman, dan nyaman meliputi jaringan jalan, drainase, sanitasi, air bersih, dan tempat sampah. 


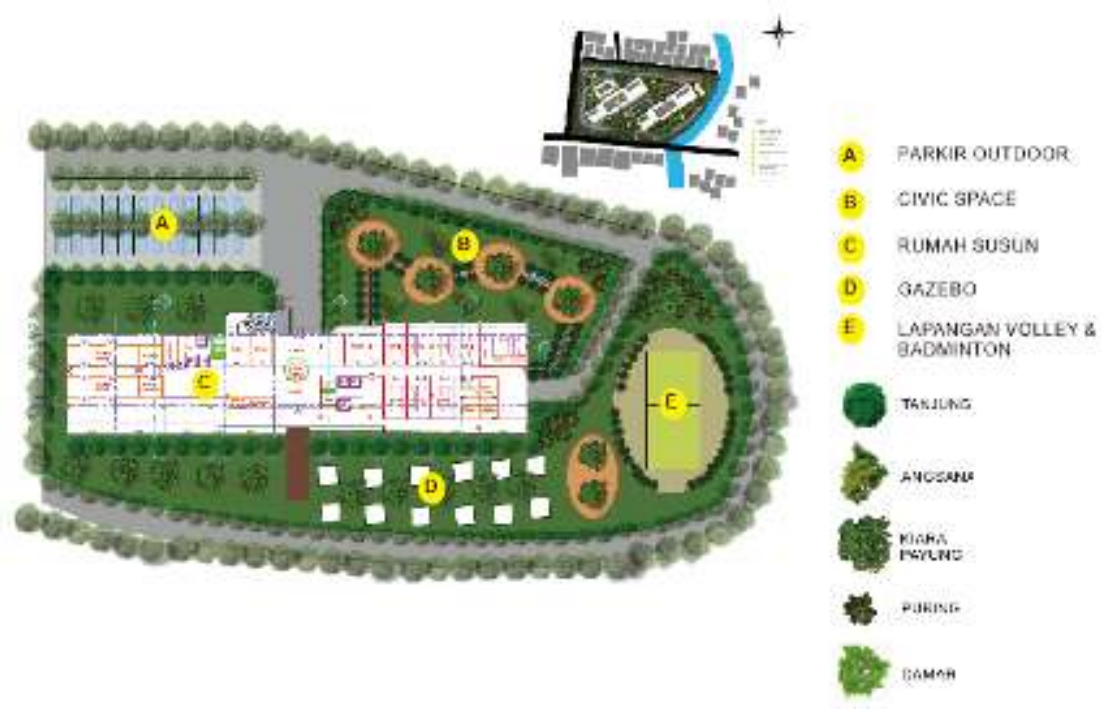

Gambar 7. Site Plan/Rencana Tapak

Sedangkan "sarana rumah susun" adalah fasilitas dalam lingkungan hunian rumah susun yang berfungsi untuk mendukung penyelenggaraan dan pengembangan kehidupan sosial, budaya, dan ekonomi meliputi sarana sosial ekonomi (pendidikan, kesehatan, peribadatan dan perniagaan) dan sarana umum (ruang terbuka hijau, tempat rekreasi, sarana olahraga, tempat pemakaman umum, sarana pemerintahan, dan lain-lain). Rancangan arsitektur untuk lahan, sarana dan prsarana akan diwujudkan pada Rencana Tapak, Denah, Tampak dan Potongan.

Bangunan Rumah susun Jetisharjo terdiri dari 8 lantai dan 2 basement, terdapat variasi denah bangunan dengan penambahan dan pengurangan yang difungsikan sebagai taman dan tempat berkumpul outdoor. Basement difungsikan sebagai ruang servis dan parkir mobil dan motor untuk penghuni rumah susun (lihat Gambar 7. Site Plan/Rencana Tapak).

\subsection{Tampak Fasad}

Desain fasad bangunan menggunakan aplikasi green fasad dengan 3 tipe, yaitu pada dinding, teras dan bukaan (City of Mebourne, 2013). Pada dinding menggunakan modul dengan tanaman selada pada fasad timur-utara dan alamanda \& bunga air mata pengantin pada fasad barat-selatan. Balkon pada tiap kamar dapat dijadikan media tanam dengan tanaman tomat dan sawi pada sisi balkon bagian dalam dengan metode vertikultur. Pada bagian bukaan menggunakan aplikasi gantung dengan menggunakan pipa paralon. Dengan demikian para penghuni dapat menghasilkan sayuran dari lahan sendiri. 
a. Aplikasi Green Façade dapat dilihat pada Gambar 8 dan 9.

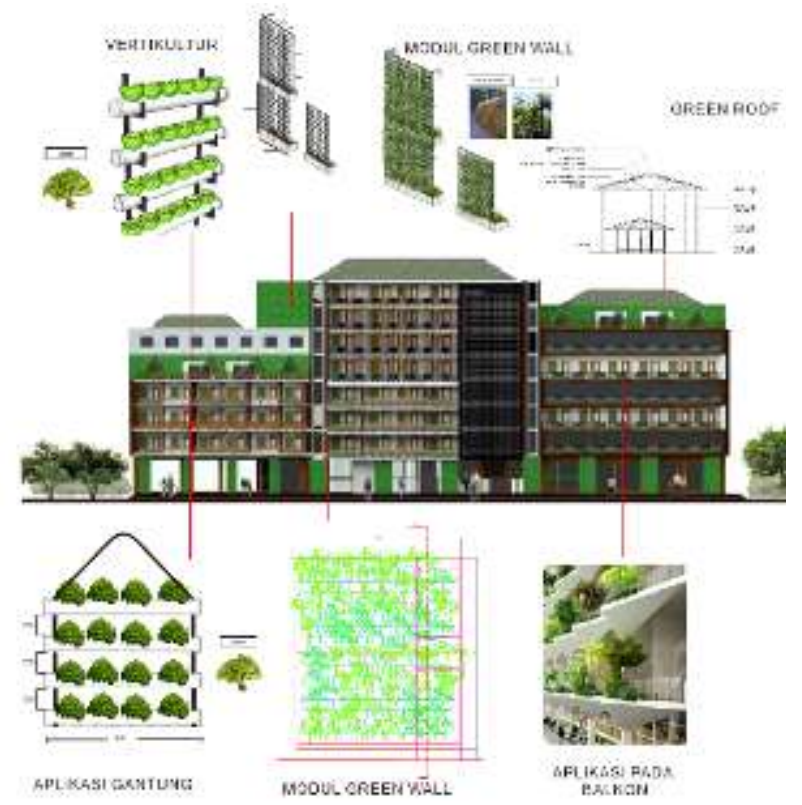

Gambar 8. Green Facade

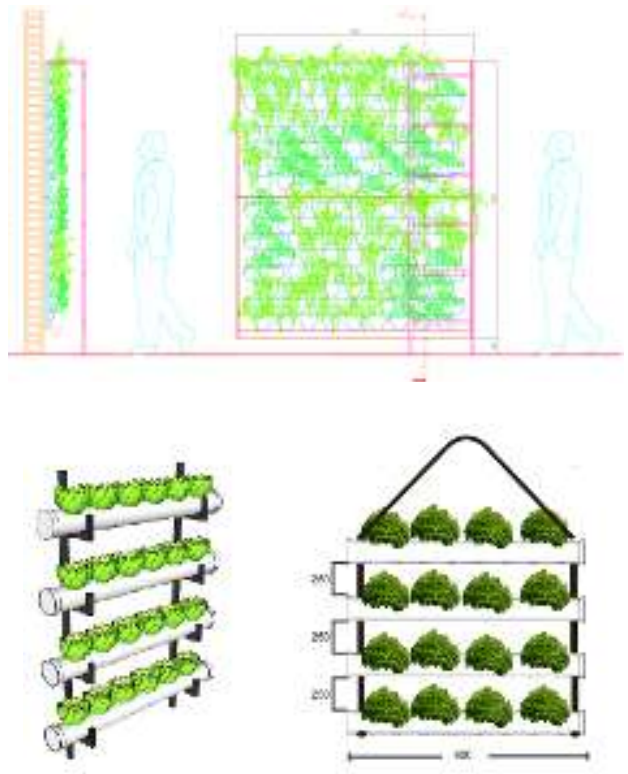

Gambar 9. Modul Green Facade

Dasar aplikasi Green Facade acuan rancangan jenis sistem dinding hijau di mana tanaman merambat dari tanah hingga menutupi struktur pendukung selubung bangunan yang ditempatkan pada dinding, teras, dan atap bangunan (CABE, 2006). Implementasi green fasad di lapangan masih sangat kurang, sehingga rancangan green facade tersebut akan memberikan hal baru di lingkungan kawasan perencanaan kampung Jetisharjo.

\section{b. Modul Green Roof}

Rancangan modul Green Roof didasarkan pada pola dan luasan atap dengan jenis tanaman produktif untuk sayuran tertentu yaitu sawi sebagai ciri khas dan kemudahan produksi.

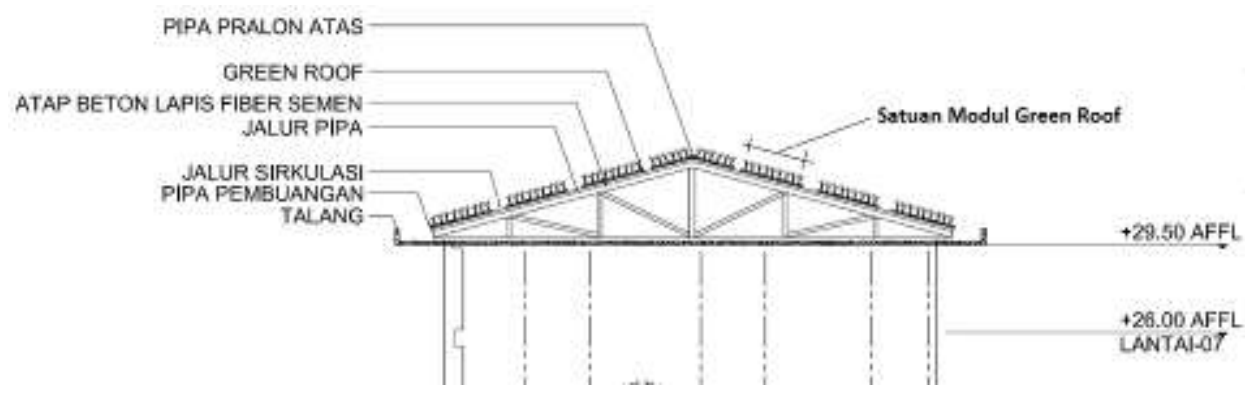

Gambar 10. Modul Green Roof 
c. Eksterior Rumah Susun Jetisharjo

Rumah Susun Jetisharjo dengan konsep Green Landscape (CABE, 2016) dan Green Facade (City of Melbourne) ini merupakan penataan kawasan permukiman yang terdapat pada kampung wisata, hunian vertikal ini menghadirkan suatu konsep tempat tinggal yang lebih tertata dan sesuai dengan kebutuhan penghuni. Pada fasad bangunan menggunakan aplikasi green fasad dengan tanaman produktif dan tanaman hias jadi selain mempercantik bangunan, menurunkan suhu ruangan juga dapat dimanfaatkan hasilnya.

Pada bagian lansekapnya terdapat suasana yang sejuk dan asri yang didukung dengan fasilitas lain seperti civic space sebagai area berkumpul sehingga penghuni dan wisatawan yang berkunjung dapat merasa nyaman, selain itu dengan penekanan tema ini juga memberikan dampak positif bagi lingkungan dengan menggunakan aplikasi green landscape dimana vegetasi menaungi perkerasan sebesar $40 \%$ dari luas perkerasan (CABE, 2006). Perkerasan yang digunakan antara lain grass block dan pervious concrete pavement yang tetap dapat ditembus oleh air sehingga air yang mengenai permukaan perkerasan ini tetap dapat meresap ke dalam tanah.

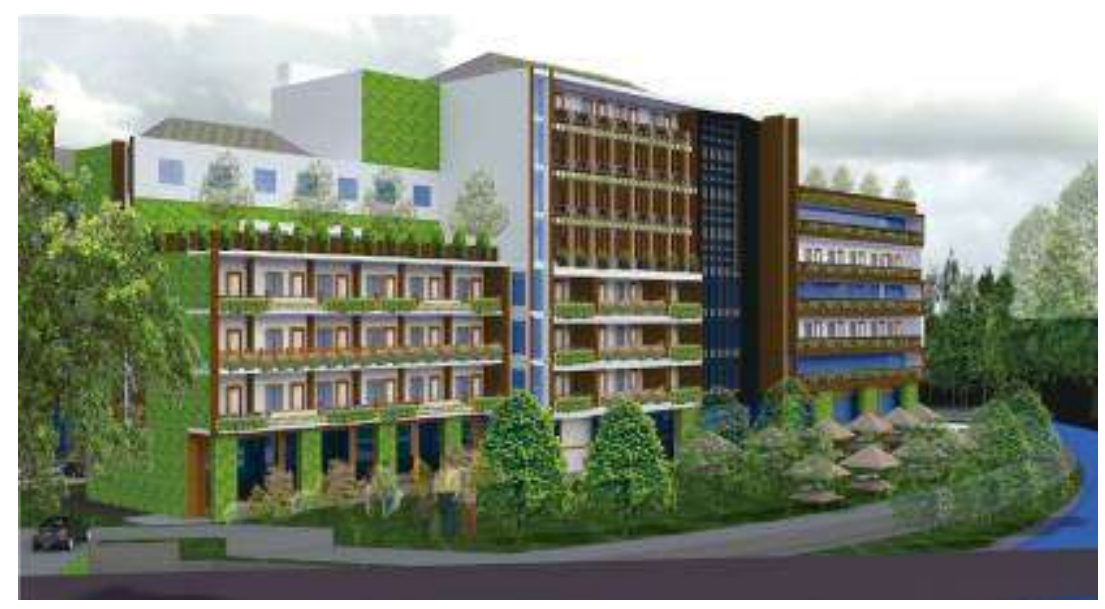

Gambar 11. Fasad Hijau dan Lansekap Hijau Rumah Susun Jetisharjo

d. Civic Space, Tree and Woodland, and Kind of Vegetation

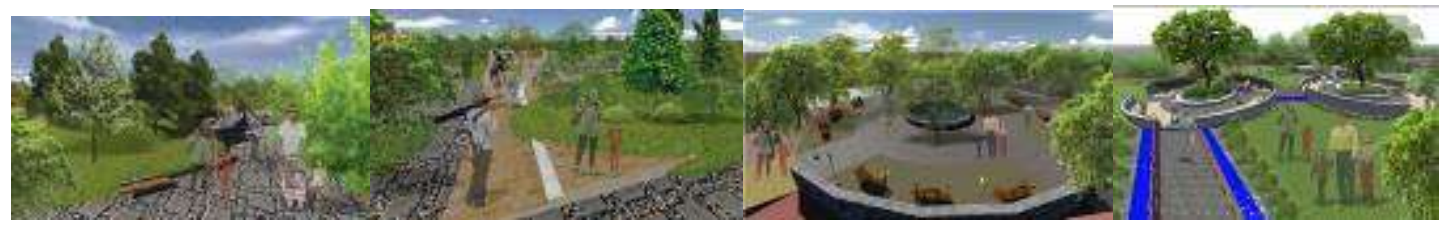

Gambar 12. Suasana Civic Space di Lingkungan Rumah Susun Jetisharjo 
Pada bagian landscape terdapat fasilitas sosial yaitu berupa ruang berkumpul dengan suasana yang sejuk dengan memasukkan unsur alami yaitu vegetasi dan air yang didasarkan pada teori atau pendekatan civic space (CABE, 2006). Ruang berkumpul/civic space ini di dalamnya terdapat 3 elemen:

1) Tree and Wood Strategy untuk menghasilkan suasana ketenangan (Gambar 11 dan Gambar 12):

a) Hard material, yaitu rancangan jalan lingkungan dan jalur pedestrian baik untuk fasilitas warga maupun wisatawan

b) Soft material, yaitu berupa tanaman seperti kolam dan pepohonan tanjung, kiara payung, puring, damar

2) Civic Space (lihat Gambar 11 dan Gambar 12):

a) Elemen pendukung (tempat duduk/kursi taman, gazebo) dan

b) Elemen alami: pepohonan, terdapat kolam air, air mancir, tepian sungai, dsb.

3) Kind of Vegetation (lihat Gambar 7, Gambar 12, dan Gambar 13):

a) Tanaman penyerap polusi: spider plant, pakis boston, palm bambu, puring, dsb.

b) Ukuran tanaman disesuaikan dengan rancangan posisi elemen lansekap dengan perawatan lansekap dilakukan oleh pengelola dan kerjasama dengan penghuni.

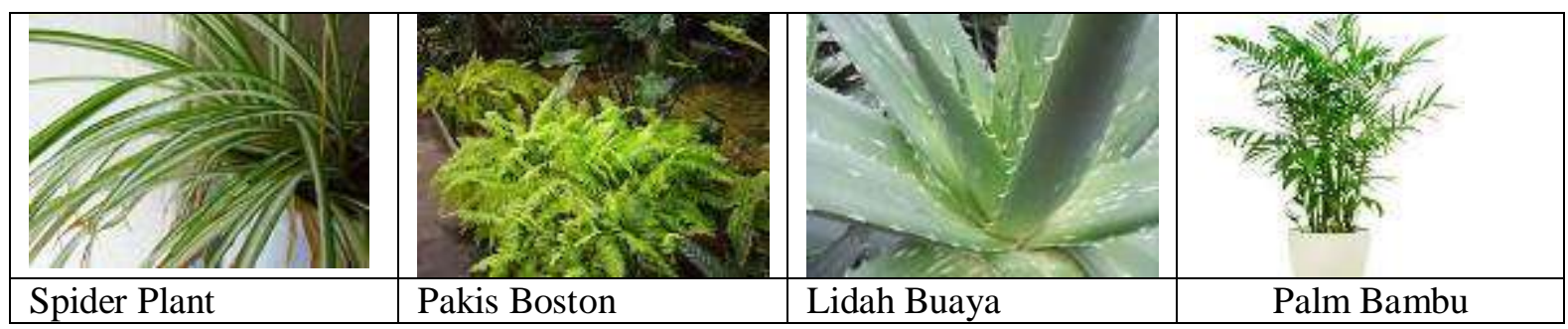

Gambar 13. Jenis Tanaman Penyerap Polusi

Sehingga rancangan yang dicapai akan mampu mendukung suasana alami dan ketenangan (CABE, 2006) dan akan mampu mendukung aktivitas rumah susun Jetisharjo secara sosial-ekonomilingkungan dimana ketiganya saling berkaitan untuk mendukung visi kawasan sebagai kawasan wisata dan kawasaan multi etnik suku dan golongan untuk saling berinteraksi. 


\section{KESIMPULAN DAN SARAN}

\subsection{Kesimpulan}

Dari hasil analisis dan pembahasan yang dikaji diperolaeh kesimpulan bahwa kawasan kampung wisata Jetisharjo ini merupakan suatu kawasan yang memiliki potensi wisata yang potensial untuk pembangunan rumah susun campuran antara penduduk asli dan pendatang, serta terdapat variasi klas ekonomi untuk tinggal bersama dengan perbedaan tinggi lantai. Fasilitas pendukung berupa ruang-ruang usaha dan civic space yang mewadahi aktivitas masyarakat lokal untuk kegiatan sosial budaya, perdaangan dan pariwisata berada di lantai 1 untuk meperkuat green lansecape. Sedangkan Green facade berupa green wall dan green roof pada rumah susun Jetisharjo yang langsung terkena matahari akan dimanfaatkan untuk tanaman sayuran slada sebagai cirikas sayuran Rumah Susun Jetisharjo dengan pertimbangan kemudahan produksi dan pemasaran.

\subsection{Saran}

Pengembangan dan penataan kawasan Jetisharjo untuk rumah susun dengan variasi penghuni sebaiknya didorong untuk meningkatkan ketahanan sosial sebagai tolok ukur civic space yang efektif. Sehingga pemerintah kota Yogyakarta perlu mengembangkan sebuah pilot project dengan perencanaan dan perancangan berbasis pada potensi masyarakat Jetisharjo, terutama tokoh masyarakat. Sosialisasi dan pelatihan perlu dilakukan untuk mendukung terwujudnya green landscape dan green facade.

\section{DAFTAR PUSTAKA}

Asikin, Damayanti., dan Rinawati P. Handajani, Sigmawan Tri Pamungkas, Haru A. Razziati, 2013, Identifikasi Konsep Arsitektur Hijau di Permukiman DAS Brantas Kelurahan Penanggungan Malang, Jurnal RUAS, Volume 11 N0 1, Juni 2013, ISSN 1693-3702

BPS Kota Yogyakarta, 2012, Yogyakarta Dalam Angka 2012, Yogyakarta: Bappeda Kota Yogyakarta http://jogjakota.bps.go.id/index.php/publikasi/index?Publikasi page=2

CABE, 2006, Green Space Strategies: a good practice guide, London: Spellman Walker

City of Melbourne, 2013, Victoria's Guide to Green Roofs, Walls \& Facades," Melbourne: Growing Green Guide

Nurfeta, Cherya Mayndra, 2011, Rumah Susun di Yogyakarta, Yogyakarta: Program Studi Arsitektur, Universitas Atma Jaya 
Direktorat Jenderal Penataan Ruang, Departemen Pekerjaan Umum."Peraturan Zonasi sebagai Perangkat Pengendalian Pemanfaatan Ruang”15 Januari 2010 http://www.slideshare.net/prasetyosampurno/peraturan-zonasi

Environmental Planning and Climate Protection Department, 2010, Green Landscaping Guideline, Durban: Durban Government

Karyono, Tri H., 2010, Green Architecture, Jakarta: Raja Grafindo Persada

Nurfeta, Cherya Mayndra, 2013, Kampung Vertikal Bantaran Sungai Code Yogyakarta dengan Pendekatan Arsitektur Organik, Yogyakarta: Prodi Arsitektur, Universitas Gadjah Mada,

Pangkerego, Gabriel Efod Virant, 2014, “Perancangan Kembali Kawasan Perumahan Kampung Pulo di Tepi Sungai Ciliwung Provinsi DKI Jakarta”. Bandung: Institut Teknologi Bandung

Putra, Agung Suryajaya, 2013. “Rumah Susun Kali Jagir di Surabaya”.Surabaya: Universitas Kristen Petra

Shirvani, Hamid,1985, Urban Design Process., New York: Van Nostrand Reinh Company.

Pratopo, Totok, Wawancara Tokoh Masyarakat Kali Code, 2 Agustus s/d 4 September 2014

Suparwoko, 2013, Green Open Space Approach to the Building Mass Arrangement in Yogyakarta: Case Study of the Revitalization of the Tugu Rail Station, International Conference on QIR 2013 in Jogyakarta on 25 - 28 June 2013

Tauladan, Tunggul, 30 April 2015, Dilema Permukiman Kumuh di Kota Yogyakarta, diakses 20 Juli 2015 dari http://www.satuharapan.com/read-detail/read/dilema-permukiman-kumuh-di-kotayogyakarta 